УДК 378:373.2.011.3/373-051

DOI: 10.37026/2520-6427-2021-105-1-49-53

\section{Олександра СОКОЛОВСЬКА,}

доктор філософії в галузі освіти, дочент, доиент кафедри дошкільної освіти Миколаївського начіонального університету імені В. О. Сухомлинського,

м. Миколаїв, Україна

ORCID: 0000-0301-937316

e-mail:kaplunova09@ukr.net

Ірина СІЧКО,

доктор філософії в галузі освіти, доиент, доцент кафедри початкової освіти Миколаївського начіонального університету імені В. О. Сухомлинського,

м. Миколаїв, Україна

ORCID: 0000-0002-5574-5806

e-mail: sichko.iryna@gmail.com

\title{
ЗАСТОСУВАННЯ ІННОВАЦІЙНИХ ТЕХНОЛОГІЙ У ПРОФЕСІЙНІЙ ПІДГОТОВЦІ МАЙБУТНІХ ПЕДАГОГІВ ДОШКІЛЬНОЇ ТА ПОЧАТКОВОЇ ОСВІТИ ДЛЯ РОБОТИ В УМОВАХ НОВОЇ УКРАЇНСБКОЇ ШКОЛИ
}

\begin{abstract}
Анотація. У статті розглянуто актуальні проблеми професійної підготовки майбутніх педагогів дочкільної і початкової освіти, зокрема їхню готовність до змін в умовах реалізації Конщепції «Нова українська школа». Особливу увагу закиентовано на важливості професійного розвитку майбутнього педагога та його готовності до роботи в умовах Нової украӥнської школи. Схарактеризовано провідну роль дисчиплін психолого-педагогічного ииклу, окремих методик, умови ефективної професійної підготовки майбутніх педагогів.

Проаналізовано наукові прачі відомих украӥнських дослідників стосовно понять «технологї», «інноваційні технологї̈». У ході наукового пошуку встановлено, що одним із найефективніших шляхів професійної підготовки майбутніх педагогів є використання інтерактивних форм і методів навчання, а також упровадження дистаниійних технологій навчання, щео неабияк підвищують якість підготовки
\end{abstract}

в закладі вищзої освіти. Доведено доиільність використання інноваиійних технологій у практиці дошкільної та початкової освіти. Інновачійні технологї розглянуто не тільки як технології навчання загалом, а й передусім як технологї формування професійно успішного майбутнього педагога в умовах модернізації освітньої системи, що сприяє саморозвитку $i$ самовдосконаленню особистості.

Професійна успішність майбутніх педагогів представлена як процес і результат діяльності, щзо характеризується спрямованістю на професійний саморозвиток і професійні досягнення. Доведено, щзо інновачійні технологї впливають на формування професійних якостей, розвиток мислення майбутнього педагога як успішної особистості, здатною конкурувати на ринку праці.

Ключові слова: Нова украӥнська школа, професійна підготовка, майбутній педагог, професійний розвиток, технологія, інноваційні технології.

\author{
Oleksandra SOKOLOVSKA, \\ PhD., Associate Professor, \\ Associate Professor of Preschool Education, \\ V.O. Sukhomlynskyi National University of Mykolaiv, \\ Mykolaiv, Ukraine \\ ORCID: 0000-0301-937316 \\ e-mail:kaplunova09@ukr.net \\ Iryna SICHKO, \\ PhD., Associate Professor, \\ Associate Professor of Primary School Education, \\ V.O. Sukhomlynskyi National University of Mykolaiv, \\ Mykolaiv, Ukraine \\ ORCID: 0000-0002-5574-5806 \\ e-mail: sichko.iryna@gmail.com
}




\section{APPLICATION OF INNOVATIVE TECHNOLOGIES IN PROFESSIONAL TRAINING OF FUTURE TEACHERS OF PRESCHOOL AND PRIMARY EDUCATION FOR WORKING IN CONDITIONS OF NEW UKRAINIAN SCHOOL}

\begin{abstract}
The article deals with the current problems of professional future teachers training and their readiness to work in the conditions of New Ukrainian School, reveals the importance of innovative technologies. The peculiarities of teachers' readiness for changes in the conditions of the Concept «New Ukrainian School» realization are substantiated, the emphasis is made on importance of professional development of the future teacher. The authors of the article pay attention to the organization of the educational process of the higher educational institution of pedagogical orientation under the conditions of Ukraine's integration into the European educational space by training of the new worldview future teachers.
\end{abstract}

The proposed article analyzes the scientific works of the leading Ukrainian researchers on the analysis of the concepts of "technology», "innovative technologies». The research found that one of the most effective ways of future teachers training is the use of interactive forms and methods of teaching and implementation of distance learning technologies that significantly improve the quality of future teachers training in higher education institutions.

The leading role of disciplines of psychological and pedagogical cycle, specific methods, and conditions of effective professional training of future teachers is defined. The expediency of using innovative technologies in the practice of preschool and primary school education by professional teachers has been proved. The authors consider innovative technologies not only as learning technologies, but also as technologies for forming a professionally successful future teacher in the modernization of the educational system, which contributes to the development of personality, its self-development and self-improvement. Different forms of training (traditional, distance), methods of situations of success application at different stages of teacher professional success formation are defined. Professional success of future teachers is defined as a process and result of activities characterized by a focus on professional self-development and professional achievement. It is proved that innovative technologies affect the formation of professional qualities, the development of future teacher thinking as a successful person who can compete in the labor market.

Key words: New Ukrainian School, professional training, future teacher, professional development, technology, innovative technologies.

Постановка проблеми. На сучасному етапі розвитку у вітчизняній освіті відбуваються кардинальні зміни, зумовлені інтеграцією України до світового співтовариства та переходом до європейських стандартів якості.

Провідною метою кожної освітньої реформи, зокрема і тих, що відбуваються тепер, є підвищення якості освіти. Одним із чинників, які забезпечують якість освіти, $є$ підготовка педагогічних кадрів. У цих умовах українська система освіти опинилася перед необхідністю значного підвищення професійної компетентності педагогів, їхнього професійного розвитку та саморозвитку.
Підготовка майбутніх фахівців педагогічних професій актуальна в державній політиці загалом та в сучасній педагогічній теорії та практиці України зокрема. Про це свідчать Концепція «Нова українська школа» (2016), Закони України «Про вищу освіту» (2014) та «Про освіту» (2017), «Концепція розвитку педагогічної освіти» (2018). Саме в цих нормативних документах наголошується на необхідності забезпечення майбутніх педагогів якісною професійною підготовкою, показником якої є успішна педагогічна діяльність у закладах дошкільної та початкової освіти. Проблема змін в освіті постійно перебуває на контролі громадської думки. Суспільство вимагає професійної підготовленості, формування професійної суб'єктивності в процесі набуття педагогічної освіти майбутніми педагогами.

Формування висококваліфікованих педагогічних кадрів з інноваційним типом мислення, розвиненою світоглядною культурою, здатних усвідомлювати місце та роль освітніх процесів у світовому культурному просторі $є$ стратегічним орієнтиром розвитку українського суспільства. Із прийняттям Закону України «Про вищу освіту» розпочато модернізацію професійної підготовки майбутніх педагогів, здатних швидко адаптуватися до нових вимог та підвищення якості освітньої діяльності в закладах дошкільної та початкової освіти, спроможних розширювати власні межі володіння науково обгрунтованими інноваційними педагогічними й інформаційними технологіями.

Особливої актуальності у зв'язку з цим набувають модернізаційні процеси у сфері дошкільної та початкової освіти й підготовки фахівців до іiї реалізації. Зокрема дошкільна освіта як перша освітня ланка має швидко реагувати на сучасні культурні запити, збагачувати знання дитини необхідною якісною інформаціє, допомагати їй реалізувати свої природні здібності, орієнтуватися на загальнолюдські й національні цінності.

Запровадження нового змісту освіти, реалізація Концепції «Нова українська школа», якість теоретичної та практичної підготовки педагогів розглядається як основа розвитку держави. Це зумовлює підвищення вимог до майбутніх педагогів як дошкільної, так і початкової освіти та необхідність удосконалення їхньої професійної підготовки. Як наслідок - важливим завданням $є$ врахування сучасних методів та технологій, спрямованих на оновлення системи освіти відповідно до вимог часу, надбань науки, культури і практики.

3 огляду на зазначене вище 3. Н. Курлянд зауважує: «Європейські дослідники вважають, що нинішня педагогічна освіта не забезпечує достатніх знань і вмінь із питань теорії, методики та техніки виховної роботи; достатнього оволодіння дидактикою (теорією, закономірностями і технологією навчання), яка $€$ основою шкільної діяльності; достатніх знань про людину як майбутнього об'єкта педагогічного впливу; 
відповідної підготовки для вирішення виховних завдань у процесі навчання» (Курлянд та ін., 2007, с. 213).

Розвиток інноваційних технологій потребує змін у вимогах до компетентностей майбутніх педагогів. У зв'язку з цим перед вищою педагогічною школою України стоїть завдання підготовки конкурентоспроможних фахівців на світовому ринку праці, які поєднують глибокі фундаментальні теоретичні знання та практичну підготовку зі сформованими загальними (універсальними, ключовими) компетентностями, що характеризують майбутнього педагога як професіонала.

Аналіз наукових досліджень і публікацій. Питанням підготовки майбутніх педагогів присвячено праці філософів, педагогів, психологів. Особливості педагогіки вищої школи та педагогічної діяльності загалом досліджували В. Андрущенко, В. Берека, І. Бех, Я. Болюбаш, Е. Васильева , Б. Вітюк, О. Власенко, I. Волощук, В. Гринько, М. Гриньова, В. Павлович, А. Печенюк, Г. Попова, Г. П'яткова, М. Ярмаченко. Підготовці майбутніх педагогів присвятили свої праці С. Максименко, О. Мороз, О. Падалка, І. Сіняговська, В. Юрченко.

Проблему інновацій в освіті досліджували як зарубіжні (А. Дуглас, П. Зеус, Д. Лі, Дж. Уїтмор, Г. Шкалок), так і вітчизняні педагоги (І. Підласий, О. Пометун, О. Романовський, О. Сухомлинська). Використання ІКТ в освітньому процесі висвітлювали у своїх роботах В. Биков, О. Іваницький, М. Кадемія, Г. Селевко. Особливості формування освітнього середовища на основі інформаційних технологій розглядали С. Васильченко, О. Гора, В. Гераськіна, Н. Клемешева, Л. Панченко.

Питанням професійної підготовки педагогів у закладах вищої освіти присвячено праці С. Вітвицької, І. Ляхової, Н. Мачинської. Шляхи вирішення проблеми якості освіти досліджували В. Гуменюк, С. Ніколаєнко, педагогічну культуру педагога - В. Гриньова, I. Ісаєв; роль пазааудиторної роботи в розвитку професійної майстерності - Р. Абдулов, С. Захаріна, Л. Онучак.

Грунтовний аналіз науково-педагогічної літератури, дисертаційних досліджень, монографій, публікацій із метою уточнення понять «інноваційна освіта» й «інноваційна педагогічна діяльність» окреслено у дослідженні Н. Гарань (2007, с. 44-51).

Аналіз змісту педагогічної підготовки майбутніх педагогів у зарубіжних країнах свідчить, що провідною ланкою у професійній підготовці є педагогічна практика. Вона має визначальний вплив на якість професійної підготовки майбутніх педагогів.

Незважаючи на достатню кількість наукових досліджень, присвячених проблемі застосування різноманітних технологій у підготовці майбутніх педагогів, засоби інноваційних технологій у контексті Нової української школи (далі - НУШ) досі ніким не розглядалися.

Мета статті полягає в обгрунтуванні необхідності застосування інноваційних технологій у підготовці майбутніх педагогів закладів дошкільної та початкової освіти в контексті сучасних вимог, а також чинників їх професійного становлення та готовності до реалізації Концепції «Нова українська школа».

Виклад основного матеріалу дослідження. Освітній процес сучасного закладу вищої освіти (далі - 3ВО) спрямований на формування освіченої особистості, здатної до оновлення своїх знань, високої професійної компетентності, оволодіння сучасними технологіями, системою управління й організації праці вчителя і вихователя в умовах ринкової економіки.

Від майбутнього педагога вимагається орієнтація на досягнення високої професійної майстерності, яка має поєднуватись із теоретичними знаннями і вмінням швидко освоювати нові галузі.

Готовність педагога до професійної діяльності - надзвичайно складний процес у житті зростаючої особистості. Він передбачає взаємодію певних компонентів (мотиваційно-орієнтаційного, змістовно-операційного й оцінно-рефлексивного) й характеризується такими показниками: спрямованість педагога на інновації; орієнтація методичних структур на забезпечення індивідуальних особливостей підготовки педагога; вироблення на цій основі нетрадиційних форм і методів освітньої роботи; підвищення професійної майстерності педагога (Курлянд та ін., 2007, с. 210).

Педагог є безпосереднім учасником освітянських перетворень, які вимагають зміни його діяльності на нові педагогічні спрямування. У закладах дошкільної та початкової освіти важливе місце відведено саме особистості педагога, його комунікативним умінням та здатності встановлювати діалог $з$ дітьми дошкільного віку та молодшими школярами, а також розуміти й сприймати переконання колег у складному взаємозв'язку професійного розвитку. Відповідно метою професійного розвитку є підготовка майбутніх педагогів до успішної роботи в умовах НУШ; досягнення дітьми дошкільного віку та молодшими школярами високих стандартів навчання і розвитку, які залежать від упровадження педагогами інноваційних технологій.

Інноваційнім технологіям відведено особливу роль у процесі професійної підготовки майбутніх педагогів, здатних до змін організації освітнього процесу, його змісту, форм і методів, а також пошуку нових підходів до педагогічної діяльності під час переходу від традиційних форм навчання до нестандартних методів, адже саме вони сприяють підвищенню та вдосконаленню професійної підготовки здобувачів освіти.

Поняття «інновація» походить від латинського терміна «innovatio, nоvo» (змінювати, поновлювати, винаходити) й означає уведення чогось нового (Климова, 2013, с. 2). У педагогічній практиці під інновацією розуміють нововведення, щзо поліпшує хід і результати освітнього проиесу.

I. Дичківська під «інновацією» розуміє оригінальні новаторські засоби, способи та прийоми педагогічних дій, а інноваційні педагогічні технології трактує як «цілеспрямоване, систематичне й послідовне впровадження в практику оригінальних, новаторських способів, прийомів педагогічних дій і засобів, що охоплюють цілісний освітній процес - від визначення його мети до очікуваних результатів» (Дичківська, 2004, с. 339). На думку вченої, інноваційна педагогічна діяльність полягає в розробці, поширенні чи застосуванні освітніх інновацій. Відповідно метою будь-якого нововведення $\epsilon$ підвищення ефективності педагогічного процесу, адже ефективність нововведення залежить від досягнутого завдяки йому корисного ефекту, тривалості використання інноваційної освітньої технології, витрат на її впровадження (Дичківська, 2004, с. 60-65).

Термін «технологія» у перекладі з грецької означає «наука про мистецтво» (texne - мистецтво, майстерність; logos - слово, навчання). У педагогічній 
літературі вживають такі поняття, пов'язані з технологією: «педагогічна технологія», «освітня технологія», «технологія навчання». Освітня технологія пов'язана 3 організацією освітніх систем та освітніх закладів.

Під освітньою технологією, за Н. Кошечко, розуміється сукупність засобів, форм і методів навчання, спрямованих на формування необхідних знань, умінь, навичок, представлених за відповідною спеціальністю. Крім того, дослідниця зауважує, що освітню технологія варто характеризувати як модель спільної роботи викладача та студентів щодо планування, організації та проведення реального процесу навчання за умови забезпечення комфортності для всіх суб'єктів освітньої діяльності. Вибір освітньої технології - це завжди вибір стратегії, пріоритетів, системи взаємодії, тактик навчання та стилю роботи викладача зі студентами (Кошечко, 2015, с. 35-38).

Питання застосування технології створення успіху у навчанні розкривають у своїх роботах О. Бєлкіна, I. Лернера, М. Махмутова, М. Венчер, М. Лисіна, Г. Люблінська, В. Лукіна.

У наукових дослідженнях останніх років передусім зосереджено увагу на аналізі: технологій та методиці їх застосування в закладах освіти (I. Велика, Н. Тернавська); методів і прийомів технології, які можна успішно використати, враховуючи різі типи схильності до навчання дітей (А. Сівак); готовності педагога до використання у навчанні ситуації успіху (Л. Чемоніна). Зауважимо, що технологія «створення ситуації усniху» набуває у сучасних ЗВО неабиякої популярності серед студентів, які на сьогодні змушені адаптуватися до нових форм організації освітнього процесу (дистанційне навчання, онлайн-навчання на платформі ZOOM тощо), особливостей взаємодії, складності навчального матеріалу.

Дистаниійне навчання - універсальна форма навчання, що базується на використанні можливостей широкого спектра традиційних, а також нових інформаційних, телекомунікаційних технологій і технічних засобів, які створюють для користувача умови вільного вибору дисциплін, діалогового обміну з викладачем без урахування відстані та часу (Курлянд, 2007, с. 213).

Ефективною системою дистанційного навчання $\epsilon$ платформа Moodle (Modular Object-Oriented Dynamic Learning Environment). У своїй основі система керування навчанням дає викладачеві можливість створити вебсайт курсу й управляти доступом до нього таким чином, щоб студенти мали можливість переглядати його. Крім контролю доступу, система керування навчанням надає широкий вибір завдань, які роблять освітній курс цікавим та результативним. Викладачі факультету педагогічної та соціальної освіти Миколаївського національного університету імені В. О. Сухомлинського у професійній підготовці майбутніх педагогів ефективно поєднують традиційні та інноваційні методики, зокрема й платформу Moodle.

Майбутній педагог у професійному розвитку спроможний вийти за межі щоденної педагогічної практики та побачити свою професійну діяльність у перспективі. Це дозволяє педагогові стати висококласним фахівцем, внутрішньо приймати, усвідомлювати й оцінювати труднощі та протиріччя педагогічного процесу, самостійно і професійно вирішувати їх відповідно до власного світобачення, розглядати труднощі як поштовх до подальшого вдосконалення, подолання невдач. Розуміння педагогом своїх можливостей, перспективи професійного зростання сприяють розвитку творчості, пошуку нових форм і методів навчання. Вирішальним елементом ситуації професійного розвитку педагога $є$ можливість відчувати власну свободу і відповідальність за все, що він робить і робитиме в майбутньому.

Розбудова Нової української школи потребує педагога, який не лише творчо мислить, а й прагне самовдосконалюватися й оновлювати традиційні компетентності. Нові компетенції у закладах дошкільної та загальної середньої освіти спрямовані на: індивідуальний підхід до потреб кожної дитини; виховання їх на національних традиціях як складових освітнього процесу; створення освітнього середовища, що сприяє реалізації творчого потенціалу як учнів, так і педагогів.

У зв'язку з цим під час вивчення студентами педагогічних дисциплін доцільним є застосування комп'ютерних технологій. Наприклад, педагогічну основу навчально-контролюючої програми можуть складати тестові завдання кількох типів: із необхідністю заповнити пропуски в тексті; з вибором однієї / кількох правильних відповідей; на визначення послідовності тощо.

У процесі наукового пошуку нами було з'ясовано, що одним зі шляхів формування професійної майстерності майбутніх педагогів є використання в освітньому процесі ЗВО таких інноваційних технологій, як: диференційоване, проблемне, імітаційне навчання; інформаційні технології; дистанційне, особистісно зорієнтоване навчання, онлайн-платформа ZOOM. Зокрема, використання інноваційних технологій відбувалося у процесі аудиторної роботи: використання нетрадиційних форм роботи, дидактичних ігор, «круглих столів»; розробка кейсів; проведення тренінгів, дискусій, конференцій, конкурсів творчих робіт; моделювання професійних завдань, презентацій та ін.

Дослідна робота передбачала декілька етапів: організаційно-підготовчий, конструкторський, технологічний, завершальний.

Проведений нами порівняльний аналіз щодо виконання студентами II курсу спеціальності 012 «Дошкільна освіта» та 013 «Початкова освіта» Миколаївського національного університету імені В. О. Сухомлинського ректорських контрольних робіт із педагогіки (дошкільна педагогіка з історією) засвідчує про абсолютну успішність (93\%) та високу якість навчання (3,3\%), що на $0,7 \%$ вища за попередні показники. До речі, студенти II курсу перебували на дистанційному навчанні у II i III семестрах.

Експериментальне дослідження засвідчує, що залучення студентів до освітньої діяльності із використанням інноваційних технологій сприяло ефективному формуванню професійних компетентностей (уміння аналізувати, застосовувати освітні технології, проводити самостійні наукові дослідження педагогічних явищ та впроваджувати їх у практику роботи, аналізувати результативність власної педагогічної діяльності, володіти інформаційно-комунікаційними технологіями).

Професійну і практичну підготовку майбутніх педагогів у Миколаївському національному університеті імені В. О. Сухомлинського здійснюють викладачі кафедр дошкільної та початкової освіти. Завданням вивчення 
педагогічних навчальних дисциплін є підготовка майбутніх педагогів до розуміння проблеми реформування дошкільної та початкової освіти, ознайомлення з проблемами дошкільної та початкової освіти в Україні та за кордоном, сформувати повагу до вихователя, вчителя, які прагнуть підвищувати професійну майстерність, застосовувати теоретичні знання у педагогічній практиці, виховувати відповідальне ставлення до майбутньої професії. Оволодіння інноваційними технологіями, які базуються на педагогічних та фахових знаннях, дозволять майбутнім вихователям та вчителям початкових класів досягти майстерності у професії.

Висновки. Зусилля всіх освітян сьогодні спрямоване на вдосконалення якості освіти, підвищення престижу професії педагога. Ключовим питанням поліпшення цієї проблеми є впровадження інноваційних технологій у закладах вищої освіти. Саме професійний педагог готовий до впровадження нового, прагне до постійного вдосконалення, працює над підвищенням своєї майстерності.

Ефективність функціонування системи дошкільної та початкової освіти значною мірою залежить від професійних педагогічних кадрів. Одним із найважливіших завдань на сучасному етапі реформування освіти в Україні є забезпечення якості підготовки педагогів на рівні міжнародних стандартів. Розв'язання цього завдання можливе за умов зміни класичних педагогічних методик та впровадження інноваційних технологій.

Перспективи подальших пошуків. Проведене дослідження не вичерпує всіх аспектів теорії та практики підготовки фахівців до професійної діяльності в умовах Нової української школи і не претендує на повноту й дослідницьку завершеність висвітлення цієї проблеми. Подальшу роботу вбачаємо в емпіричному аналізі ефективності діяльності центру В. О. Сухомлинського з позиції удосконалення методичної системи професійної підготовки майбутніх учителів початкової школи до роботи в умовах НУШ.

\section{СПИСОК ВИКОРИСТАНОЇ ЛІТЕРАТУРИ}

Нова українська школа. Концептуальні засади реформування середньої школи. URL: http://mon. gov.ua/2016/12/05/konczepcziya.pdf (дата звернення: 11.10.2020).

Про вищу освіту: Закон України від 01.07.2014 p. № 1556-VII. URL: http://zakon.rada.gov.ua/laws/ show/1556-18 (дата звернення: 12.10.2020).

Про освіту: Закон України від 05.09.2017 р. № 2145VIII. URL: https://zakon.rada.gov.ua/laws/show/214519\#Text (дата звернення: 11.10.2020).

Концепція розвитку педагогічної освіти: наказ Мiністерства освіти і науки України від 16.07.2018 р. № 776. URL: https://mon.gov.ua/ua/npa/pro-zatverdzhennyakoncepciyirozvitku-pedagogichnoyi-osviti) (дата звернення: 12.10.2020).

Педагогіка вищої школи: навч. посіб. (2007) / З. Н. Курлянд, Р. І. Хмелюк, А. В. Семенова та ін. 3-є вид., переробл. і доповн. Київ: Знання. 495 с.

Гарань, Н. (2017). Інновації у вищій освіті як запорука сталого економічного розвитку країни. Духовність особистості: методологія, теорія і практика. № 5 (80). C. 44-51.
Климова, Г. (2013). Інноваційний розвиток вищої освіти України: методологічний аспект аналізу. Право та інноваційне суспільство. URL: http://nbuv.gov.ua/ UJRN/pric 2013 1 10 (дата звернення: 11.01.2020).

Дичківська, I. (2004). Інноваційні педагогічні технології. Київ: Академвидав. 352 с.

Кошечко, Н. (2015). Інноваційні освітні технології навчання та викладання у вищій школі. Вісник Київського національного університету імені Тараса Шевченка. Педагогіка. № 1. С. 35-38.

\section{REFERENCES}

Nova ukrainska shkola. Kontseptualni zasady reformuvannia serednoi shkoly [New Ukrainian school. Conceptual principles of secondary school reform] / M-vo osvity i nauky Ukrainy. URL: https://mon.gov.ua/storage/app/ media/zagalna\%20serednya/nova-ukrainska-shkola-compressed.pdf (data zvernennia: 11.01.2020). [in Ukrainian].

Pro vyshchu osvitu: Zakon Ukrainy vid 01.07.2014 r. № 1556-VII [On Higher Education: Law of Ukraine]. URL: http://zakon.rada.gov.ua/laws/show/1556-18 (data zvernennia: 11.01.2020). [in Ukrainian].

Pro osvitu: Zakon Ukrainy vid 05.09.2017 r. № 2145-VIII [On Education: Law of Ukraine]. URL: http:// search.ligazakon.ua/1_doc2.nsf/link1/T172145.html (data zvernennia: 11.01.20̄̄0). [in Ukrainian].

Kontseptsiia rozvytku pedahohichnoi osvity: nakaz Ministerstva osvity i nauky Ukrainy vid 16.07.2018 r. № 776 [The concept of pedagogical education development: Order of the Ministry of Education and Science of Ukraine]. URL: https://mon.gov.ua/ua/npa/pro-zatverdzhennya-koncepciyirozvitku-pedagogichnoyi-osviti (data zvernennia: 11.01.2020). [in Ukrainian].

Pedahohika vyshchoi shkoly [Pedagogy of High School]: navch. posib. (2007) / Z. N. Kurliand, R. I. Khmeliuk, A. V. Semenova etc. 3-ye vyd., pererobl., dopovn. Kyiv: Znannia. 495 p. [in Ukrainian].

Haran', N. (2017). Innovatsiyi u vyshchiy osviti yak zaporuka staloho ekonomichnoho rozvytku krayiny [Innovations in higher education as a guarantee of sustainable economic development of the country]. Dukhovnist' osobystosti: metodolohiya, teoriya i praktyka. № 5 (80). S. 44-51. [in Ukrainian].

Klymova, N. (2013). Innovatsiinyi rozvytok vyshchoi osvity Ukrainy: metodolohichnyi aspekt analizu. Pravo ta innovatsiine suspilstvo [Innovative development of higher education in Ukraine: methodological aspect of analysis. Law and innovation society]. URL: http://nbuv.gov.ua/ UJRN/pric_2013_1_10 (data zvernennia: 11.01.2020). [in Ukrainian].

Dychkivska, I. (2004). Innovatsiini pedahohichni tekhnolohii [Innovative pedagogical technologies ]. Kyiv: Akademvydav. 352 s. [in Ukrainian].

Koshechko, N. (2015). Innovatsiini osvitni tekhnolohii navchannia ta vykladannia u vyshchii shkoli [Innovative educational technologies of teaching and learning in higher education]. Visnyk Kyivskoho natsionalnoho universytetu imeni Tarasa Shevchenka. Pedahohika. № 1. S. 35-38. [in Ukrainian].

Дата надходження до редакиії: 13.01.2021 p. 